\title{
Capturing, induced spawning, and first feeding of wild-caught Pseudopimelodus mangurus, an endangered catfish species
}

\author{
Dilberto Ribeiro Arashiro $^{1,2}$, George Shigueki Yasui ${ }^{1,2}$, Leonardo Luiz Calado ${ }^{2}$ \\ Nivaldo Ferreira do Nascimento ${ }^{2,3}$, Silvio Carlos Alves do Santos ${ }^{4}$, Gustavo Fonseca Shiguemoto ${ }^{1,2}$ \\ Paulo Sérgio Monzani ${ }^{2,5}$ \& José Augusto Senhorini ${ }^{1,2}$ \\ ${ }^{1}$ Institute of Bioscience, São Paulo State University, Botucatu, SP, Brazil \\ ${ }^{2}$ Laboratory of Fish Biotechnology, National Center for Research and Conservation of Continental Fish \\ Chico Mendes Institute of Biodiversity Conservation, Pirassununga, SP, Brazil \\ ${ }^{3}$ Aquaculture Center, São Paulo State University, Jaboticabal, SP, Brazil \\ ${ }^{4}$ AES Tietê, Promissão, SP, Brazil \\ ${ }^{5}$ Departament of Veterinary Medicine - FZEA, Pirassununga, SP, Brazil \\ Corresponding author: Dilberto Ribeiro Arashiro (dilbertoarashiro@ hotmail.com)
}

\begin{abstract}
This study aimed to describe a procedure for sampling, reproduction, and first feeding of the Neotropical catfish Pseudopimelodus mangurus, an endangered fish species. Wild adult $P$. mangurus specimens were collected in the Mogi Guassu River and subsequently induced to spawn in laboratory conditions. After hand-stripping, the females, the average weight of the oocytes was $143 \pm 1.6 \mathrm{~g}$, with a fecundity of $718 \pm 49.8$ oocytes $\mathrm{g}^{-1}$. The diameter of the oocytes non-hydrated was $1226.3 \pm 47.7 \mu \mathrm{m}$ to $1761.2 \pm 26.4 \mu \mathrm{m}$ after hydration. The fertilization rates were $98.00 \pm 0.63 \%$, and the hatching rate was $68.94 \pm 11.83 \%$. The first feeding was made three days post-hatching with six different treatments, in which the best results arose with sequential feeding with Artemia nauplii, Astyanax altiparanae and Prochilodus lineatus larvae. This condition resulted in a final length of $2,012.7 \pm 44.8 \mu \mathrm{m}$ by the $10^{\text {th }}$ day of the experiment, higher survival $(65 \pm 0.9 \%)$ and lower cannibalism rate $(14 \pm 0.3 \%)$. The data obtained in this study is important for the establishment of reproductive biotechniques, mass production of $P$. mangurus, and future establishment of ex-situ GenBank.
\end{abstract}

Keywords: Pseudopimelodus mangurus; catfish; conservation; GenBank; larvae; reproduction

\section{INTRODUCTION}

In the Neotropical region, 1680 fish species are considered endangered and listed in the International Union for Conservation of Nature (Toussaint et al., 2016). Such a panorama suggests research efforts, including artificial propagation, genetics, re-stocking, and biotechniques like chromosome manipulation (Piferrer et al., 2009), chimerism (Yasui et al., 2011; Nascimento et al., 2017), and ex-situ GenBank.

Among the endangered species, the bumblebee catfish Pseudopimelodus mangurus (Valenciennes, 1835) is a migratory Neotropical catfish that is ecologically relevant, serving as a food source for other species of fish, reptiles, mammals, and birds. $P$. mangurus, also known as "frogfish," belongs to the fa- mily Pseudopimelodidae and has a carnivorous feeding pattern. It can be found in the Paraná, Uruguay, Paraguay, and La Plata rivers basins (Froese \& Pauly, 2015). This species was included in the red list of endangered animals in the São Paulo State, Brazil (Bressan et al., 2009; ALESP, 2014), suggesting that conservation and reconstitution strategies including $e x$ situ GenBank and reproduction are necessary. However, in order to achieve such a preservation protocol, it is first necessary to understand fundamental aspects of this species as reproduction, incubation and first feeding to ensure mass production of juveniles for re-stocking (Luz \& Zaniboni-Filho, 2002; Murgas et al., 2012; Arashiro et al., 2018).

Artificial propagation is an important step for mass production, but the procedures to induce spawning that

Corresponding editor: Leonardo Abitia 
includes a combination of dosage, hormones, and maturation period are species-specific (Andrade \& Yasui, 2003; Godinho, 2007). Also, larval rearing is a critical step, especially within carnivorous fish, as the case of $P$. mangurus. Despite the relevance of such reproductive information, there is no protocol for reproduction and juvenile production in $P$. mangurus among the reviewed literature.

Considering the aspects mentioned above, the objective of this work was to establish protocols for the collection of sexually mature wild specimens, hormonal induction for reproduction and larval feeding of $P$. mangurus.

\section{MATERIALS AND METHODS}

All the procedures were conducted during the reproductive season of Pseudopimelodus mangurus (October 2015 to February 2018) in agreement with the Guide for the Care and Use of Laboratory Animals of the National Center for Research and Conservation of Continental Fish, Chico Mendes Institute of Biodiversity Conservation (CEUA \#010/2015).

Adult specimens were collected from the Mogi Guassu River, Cachoeira de Emas in Pirassununga City, São Paulo State, Brazil (21 ${ }^{\circ} 55^{\prime} 36.476$ "S, $\left.47^{\circ} 22^{\prime} 0.836^{\prime \prime} \mathrm{W}\right)$ under permission of the same institution (Sisbio \#55725-1). The collection was performed using line fishing at the bottom of the river. As $P$. mangurus lives at greater depths and is nocturnal, the sampling was performed from 16:00 until 24:00 h. The equipment for collection sampling included a 0.40 $\mathrm{mm}$ line, 4.0 to $7.0 \mathrm{~mm}$ hook, dead Astyanax altiparanae as bait, and a $2 \mathrm{~m}$ fishing rod with a reel. After collection, fish were immediately transported to 2,000 L circular tanks to be induced to spawn.

The females were selected based on morphological appearance, presenting a reddish papilla and a soft, protuberant ventral region (Woynarovich \& Horváth, 1983; Solis-Murgas et al., 2011). Subsequently, the fish were tagged using a $14 \mathrm{~mm}$ micro-transponder (ISSO FDC-B $12 \times 2 \mathrm{~mm}$, Animal TAG, USA), weighed, and then transferred to a $2,000 \mathrm{~L}$ circular tank with continuous water flow. The spawning was induced by injecting crude carp pituitary extract (CCPE) at $6.6 \mathrm{mg}$ $\mathrm{kg}^{-1}$, divided into two doses, 0.6 and $6 \mathrm{mg} \mathrm{kg}^{-1}, 6 \mathrm{~h}$ after the first dose. The P. mangurus males were injected with a single dose of CCPE at $2 \mathrm{mg} \mathrm{kg}^{-1}$ when females received the second dose.

At 165 degrees-hour after the injection, male gametes were sampled before females. Males were euthanized with an overdose of clove oil at $250 \mathrm{mg} \mathrm{L}^{-1}$ (Biodinamica, Ibiporã, Brazil). The testis was removed and minced in Eagle's Minimum Essential Medium with the pH adjusted to 7.8 (E-MEM, Sigma \#M0268, St. Louis, USA). A small aliquot was used to evaluate sperm motility, according to the procedures described by Yasui et al. (2015). Females were anesthetized with clove oil at $150 \mathrm{mg} \mathrm{L}^{-1}$, and stripping was performed in a glass container. The weight of total spawn was measured, and a small aliquot was weighed and fixed in $2 \%$ glutaraldehyde in Dulbecco's PBS (Sigma \#D5773, St. Louis, USA) in order to calculate the number of oocytes per gram, total fecundity (total number of oocytes) and relative weight fecundity ( $g$ of oocytes per $\mathrm{kg}$ of the female).

For fertilization, the diluted sperm was placed on the oocyte mass and immediately activated by adding water. The fertilized oocytes were incubated at $26^{\circ} \mathrm{C}$, as reported by Arashiro et al. (2018) for the incubation of P. mangurus embryos. A small aliquot (30-80 embryos) was collected randomly and followed until hatching to calculate fertilization and hatching rates. Three spawns of $P$. mangurus were obtained, using a different male and female (three couples), and each spawn was considered as a repetition (eggs were not mixed).

Embryos from each repetition were incubated separately, and three days after hatching, larvae had consumed the yolk sack and started exogenous feeding. Active and healthy larvae from each repetition were divided into six floating plastic containers $(20 \times 15 \mathrm{~cm})$ with 30 larvae and a volume of $630 \mathrm{~mL}$ of water for each (total of 18 plastic containers). Each container had a $1 \mathrm{~mm}$ nylon mesh on the lateral to permit continuous water flowing while the bottom was covered by sand, in order to prevent biofilm formation. The temperature was set at $26^{\circ} \mathrm{C}$. The six containers from each repetition received the following feeding T1: Artemia franciscana nauplii; T2: plankton; T3: dry food (Laguna larva postlarva, 55\% crude protein, Invivo Nutrição e Saúde Animal Ltda., Paulinia, Brazil) T4: Artemia nauplii and plankton; T5: Artemia nauplii, plankton and dry food; T6: Artemia nauplii, A. altiparanae and P. lineatus larvae.

The plankton used in this experiment were collected in tanks from CEPTA/ICMBio and UV-irradiated at 80

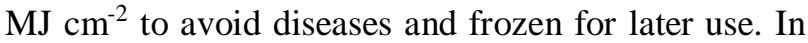
treatment 6 , the larvae of $P$. mangurus were exclusively fed with Artemia nauplii during the first three days, and, afterward, the diet was changed to larvae of yellowtail tetra (Astyanax altiparanae) and the streaked prochilod (Prochilodus lineatus) until satiation.

The containers were cleaned twice a day (08.00 and 18:00 h) with a Pasteur pipette to remove lumps of uneaten food and dead larvae. For evaluation of growth, 10 individuals from each container were daily 
collected and returned after measurement, and digital images were obtained using the stereomicroscope (Nikon SMZ 1500, Nikon, Tokyo, Japan) in combination with a CCD camera (Nikon DS-Fi, Nikon, Japan). The software NIS-AR Elements (Nikon, Tokyo, Japan) was used to capture and measure the total length $(\mu \mathrm{m})$ from the digital images. After 10 days, the survival and cannibalism rates were calculated from each container. The cannibalism rate was calculated as follows: the total number of larvae found dead during the experimentation was added to the number of larvae that survived. This total was subtracted from the number of larvae at the beginning of the experiment.

\section{Statistics}

Data are shown as mean \pm standard error. Growth performance was examined using regression analysis and ANOVA followed by the Tukey multiple range tests (for comparison of total length in the last day). In all analyses, the software Statistica (7.0, StatSoft, USA) was used with the probability set at 0.05 .

\section{RESULTS}

The weight of the captured broodstock ranged from 0.160 to $7.800 \mathrm{~kg}$. From November to December 2017, 19 Pseudopimelodus mangurus females were induced to spawn. Eighteen successfully spawned. Oocyte from 10 females was used for me diameter were obtained from 10 females.

Just after spawning and after hydration, oocytes measured 1,226.3 $\pm 47.7 \mu \mathrm{m}$ and 1,761.2 $\pm 26.4 \mu \mathrm{m}$, respectively. Female weight ranged from 0.803 to $3.492 \mathrm{~kg}$, and these reproductive data were obtained: the number of oocytes per gram (718.0 \pm 49.8$)$, fecundity $(257.6 \pm 85.9 \mathrm{~g})$, fertilization rate $(98.0 \pm$ $0.6 \%)$, and hatching rate $(68.9 \pm 11.8 \%)$. The growth of the $P$. mangurus larvae fed with different diets presented a linear regression with a determination coefficient ranging from 0.9918 (fish fed with Artemia) to 0.8375 (fish fed with dry food). Based on the angular coefficient of the resultant regression, the best growth was obtained in treatment 6 (fish fed Artemia + fish larvae). In this treatment, the estimated daily growth increments were of $1646.1 \mathrm{~mm} \mathrm{~d}^{-1}$ (Fig. 1). The final total length $(20.12 \pm 0.04 \mathrm{~mm})$ was also significantly higher in this treatment (Fig. 2).

As shown in Figure 3, the survival rate of larvae fed with Artemia nauplii and fish larvae (treatment 6) was significantly higher $(65.0 \pm 0.1 \%, P<0.05)$ than the other treatments. The other treatments (T1 to T5) presented low survival rates, ranging from 1.6 to $5 \%$. Also, the cannibalism rate was significantly lower $(P<$

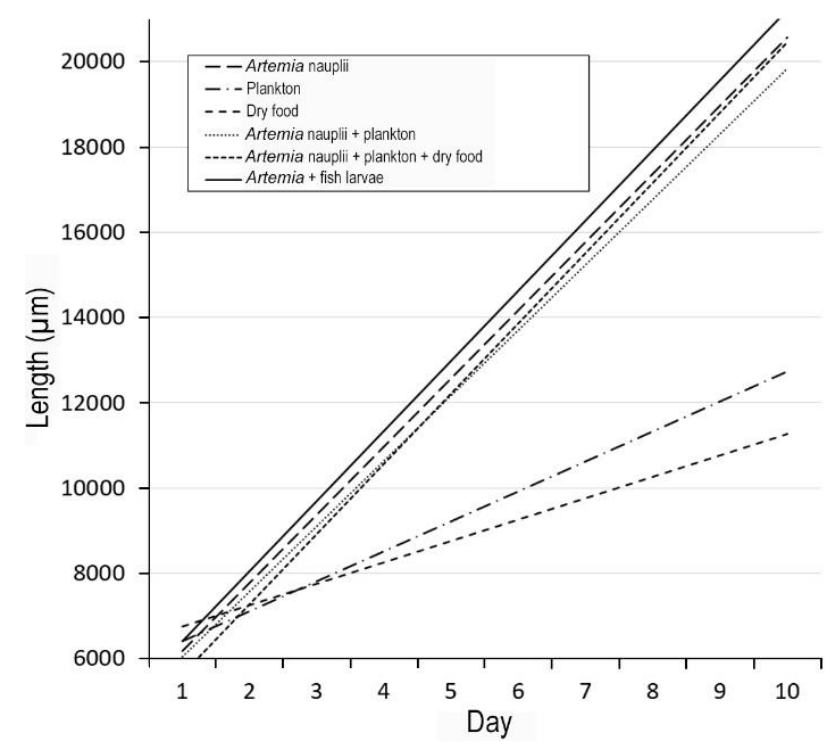

Figure 1. Growth $(\mu \mathrm{m})$ of Pseudopimelodus mangurus larvae fed with different diets. T1: Artemia: $\mathrm{y}_{3}=1597.9 \mathrm{x}$ $+4580.2 ; \mathrm{R}^{2}=0.9918 ; \mathrm{T} 2$ : plankton: $\mathrm{y}_{4}=704.21 \mathrm{x}+$ 5697.9; $\mathrm{R}^{2}=0.9439 ; \mathrm{T} 3$ : dry food: $\mathrm{y}_{5}=502.13 \mathrm{x}+6235.7$; $\mathrm{R}^{2}=0.8375$; $\mathrm{T} 4$ : plankton + Artemia: $\mathrm{y}_{1}=1532.5 \mathrm{x}+$ 4513.2; $\mathrm{R}^{2}=0.9906 ;$ T5: dry food + plankton + Artemia: $\mathrm{y}_{2}=1648.1 \mathrm{x}+3969.3 ; \mathrm{R}^{2}=0.9868 ; \mathrm{T} 6:$ Artemia + fish larvae: $\mathrm{y}^{6}=1646.1 \mathrm{x}+4752.5 ; \mathrm{R}^{2}=0.977$.

0.05) when the fish were fed with Artemia nauplii and fish larvae $(14.0 \pm 0.03 \%)$, followed by treatment 4 $(36.6 \pm 4.0 \%)$. Treatments $1,2,3$, and 5 showed high rates of cannibalism (ranging from $45.0 \pm 5.5 \%$ to 76.6 $\pm 1.0 \%)$.

\section{DISCUSSION}

The criteria for selecting females for spawning, including external morphology, abdominal inspection, and redness of the urogenital papilla, was valid for Pseudopimelodus mangurus as in the case of other Neotropical migratory species such as P. charus and Rhamdia quelen (Vieira-Sampaio \& Yoshimi, 2006). Similarly, male selection based on semen release after a gently stripping was also an effective selection procedure for mature males.

The protocol of induced spawning involves trialand-error experiments in which the main factors include the hormone, dose, and ovulation period. In this study, a general protocol using two doses of carp pituitary gland was successfully used as suggested for other fish species such as Pimelodus maculatus and Pseudoplatystoma corruscans (Arantes et al., 2013), Pseudoplatystoma fasciatum (Leonardo et al., 2004), Steindachneridion melanodermatum (Ludwig et al., 2005), and Brycon insignis (Andrade-Talmelli et al., 


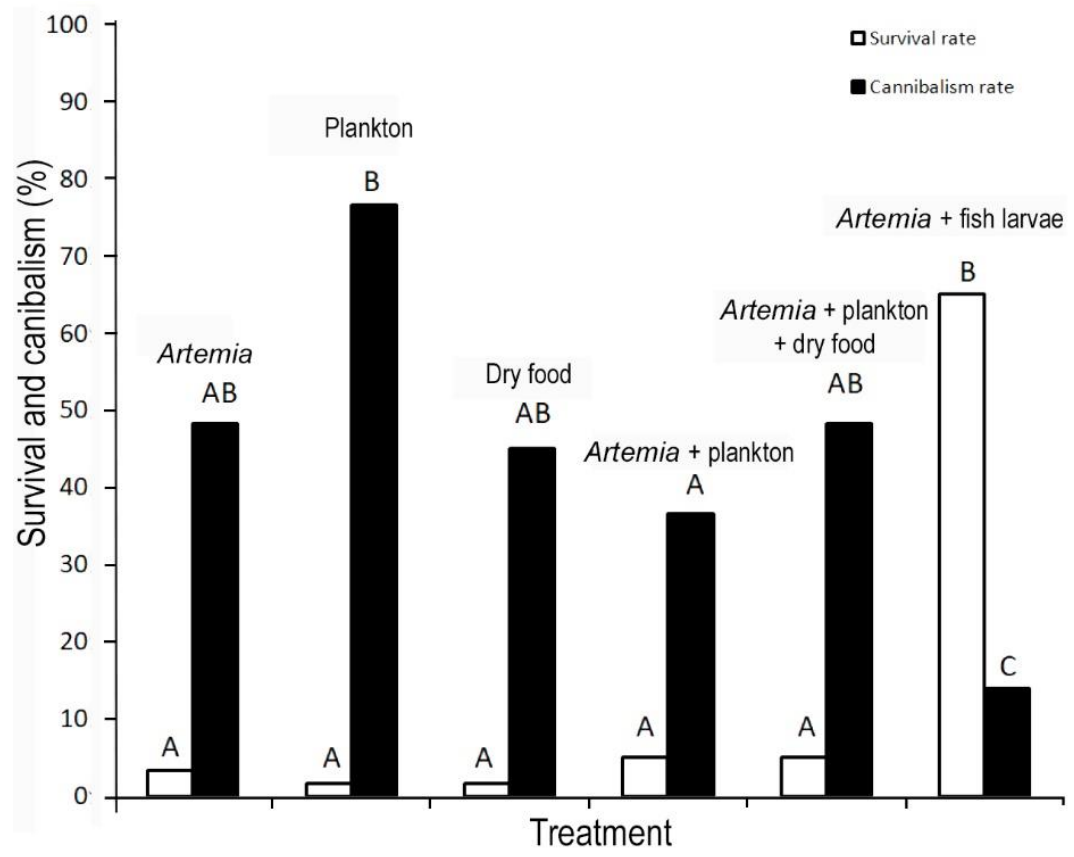

Figure 2. Survival (\%) on day 10 and cannibalism over 10 days of Pseudopimelodus mangurus larvae fed with different diets. Different letters in survival or cannibalism columns indicate significant differences.

a

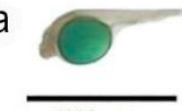

$1000 \mu \mathrm{m}$

b

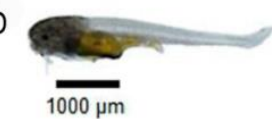

C

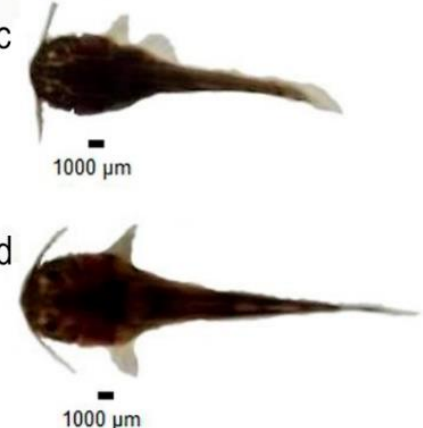

Figure 3. Larvae of Pseudopimelodus mangurus from treatment 6 (Artemia nauplii in the first three days followed by Astyanax altiparanae and Prochilodus lineatus larvae in the next days of the experiment). a) Larvae at hatching stage, b) one day, c) fifth days, and d) tenth days of the experiment.

2002). The maturation period was shorter in the case of $P$. mangurus since the final maturation occurred after six hours (165 degree-hours) after the second hormonal dose. In other Neotropical catfish species, ovulation occurs within a more extended period as in the case of $R$. quelen (311 degree-hours), P. charus (315 degreehours) (Vieira-Sampaio \& Yoshimi, 2006), Zungaru jahu (220-230 degree-hours) (Nogueira et al., 2012), $S$. melanodermatum (260 \pm 20 degree-hours) (Ludwig et al., 2005), P. corruscans and P. fasciatum (180-230 degree-hours) (Inoue et al., 2003).

In most cases, induced reproduction of migratory endangered species is performed in fish maintained in captivity, and maturation occurs during the spawning (rainy) season (Andrade \& Yasui, 2003). Such procedures require the previous domestication of the wild-caught specimens, including feeding with commercial diets and the adaptation to artificial ponds. However, the domestication process in captivity until fish reach sexual maturity can take more than two years. In this study, the wild-caught specimens were collected in the spawning areas and promptly induced to spawn, a procedure that has been an effective strategy for the initiation of an ex-situ GenBank because juveniles are rapidly obtained after broodstock capture. In addition, higher fertilization rates $(>97 \%)$ were obtained for $P$. mangurus compared with other siluriform species like Pimelodus maculatus (64.80\%), Pseudoplatytoma corruscans (79.83\%) (Arantes et al., 2013), and Zungaro jahu (92\%) (Nogueira et al., 2012). Hatching rate was also higher $(>68 \%)$ than in other siluriforms, such as P. maculatus (Arashiro et al., 2018) and Sorubim lima (Shibatta et al., 2011). 
Such a result is probably related to the hormonal induction of fish at the spawning site. In this environment, fish can find adequate conditions necessary for their gonadal development, including aspects such as nutrition and ideal spawning area.

The oocytes of the P. mangurus were smaller than the oocytes of other Neotropical siluriform species such as Z. jahu (2,400 $\mu \mathrm{m})$ (Nogueira et al., 2012), R. quelen $(2,640 \mu \mathrm{m}), P$. charus $(2,670 \mu \mathrm{m})$ (Vieira- Sampaio \& Yoshimi, 2006). However, the larval size of $P$. mangurus at hatching was higher than other Neotropical Siluriformes and presented higher growth performance when compared to $P$. charus and $R$. quelen (Vieira-Sampaio \& Yoshimi, 2006), $P$. maculatus (Luz \& Zaniboni-Filho, 2001), Pseudoplatystoma corruscans (Campagnolo \& de OliveiraNuñer, 2006). First feeding of the majority of carnivorous larvae from Neotropical fishes was achieved successfully using Artemia nauplii during the initial stages, as in the case of Lophisilurus alexandri (Luz et al., 2011), Pimelodus maculatus (Luz \& Zaniboni-Filho, 2002), R. quelen (Diemer et al., 2012), P. corruscans (Segura et al., 2004), Steindachneridion melanodermatum (Feiden et al., 2006) and S. scriptum (Schutz et al., 2008). P. mangurus had a smaller egg size, but the larvae at first feeding were larger than other Neotropical carnivorous larvae. This characteristic probably is the reason why protocols using only Artemia nauplii were not successful in this study. Bigger prey such as fish larvae (A. altiparanae and $P$. lineatus) had to be added to the diet of $P$. mangarus to reduce cannibalism and to improve growth.

Reproduction using wild-specimens, followed by the rearing of juveniles, may work synergically for GenBank since those juveniles could be easily domesticated and used for reproductive technologies such as surrogate propagation (De Siqueira-Silva et al., 2018).

In conclusion, reproduction and first feeding of $P$. mangurus were successfully achieved using the following procedure: capturing the brood stock in natural environments and immediately inducing spawning with carp pituitary extract $\left(0.6\right.$ and $6 \mathrm{mg} \mathrm{kg}^{-1}$ for females, and $2 \mathrm{mg} \mathrm{kg}^{-1}$ for males); getting testis after sacrificing males and stripping females after $165 \mathrm{~h}$ degree-hours after the second dose; doing fertilization with diluted sperm in Eagle's MEM, and feeding the larvae with Artemia nauplii in the first three days followed by fish larvae in the next days. These procedures are innovative and are important to establish conservation strategies for this endangered catfish species.

\section{ACKNOWLEDGMENTS}

The authors would like to thank the Instituto de Biociências (IBB) of Universidade Estadual Paulista (UNESP), Botucatu, São Paulo, Brazil, in addition to the Laboratory of Fish Biotechnology, CEPTA/ ICMBio, Pirassununga, Brazil. We would also like to thank Michael James Stablein of the University of Illinois Urbana-Champaign for his review services of this work. The author expresses his gratitude to the AES Tietê/ANEEL (Research \& Development Project \#0064-1052/2014) for financial support, and also for ICMBio/CEPTA for gently providing the facilities.

\section{REFERENCES}

Andrade, D.R. \& Yasui, G.S. 2003. O manejo da reprodução natural e artificial e sua importância na produção de peixes no Brasil. Revista Brasileira de Reprodução Animal, 27: 166-172.

Andrade-Talmelli, E., Kavamoto, E., Narahara, M. \& Fenerich-Verani, N. 2002., Peprodução induzida da piabanha, Brycon insignis, mantida em cativeiro. Revista Brasileira de Zootecnia, 31: 803-811.

Arantes, F.P., Sato, Y., Sampaio, E.V., Rizzo, E. \& Bazzoli, N. 2013. Spawning induction and fecundity of commercial native fish species from the São Francisco River basin, Brazil, under hatchery conditions. Agricultural Sciences, 4: 382-388.

Arashiro, D.R., Yasui, G.S., Calado, L.L., do Nascimento, N.F., dos Santos, M.P., do Santos, S.C.A., LevyPereira, N., Monzani, P.S., Siqueira-Silva, D.H. \& Senhorini, J.A. 2018. Synchronizing developmental stages in Neotropical catfishes for application in germ cell transplantation. Zygote, 26(2): 135-148.

Assembleia Legislativa de São Paulo (ALESP). 2014. Decreto $N^{\circ}$ 60.133, de 7 de Fevereiro de 2014.

Bressan, P.M., Kierulff, M.C.M. \& Sugieda, A.M. 2009. Fauna ameaçada de extinção no Estado de São Paulo. Fundação Parque Zoológico de São Paulo, Secretaria do Meio Ambiente, São Paulo.

Campagnolo, R. \& de Oliveira Nuñer, A.P. 2006. Sobrevivência e crescimento de larvas de surubim, Pseudoplatystoma corruscans (Pisces, Pimelodidae), em diferentes densidades de estocagem. Acta Scientific, 28: 231-237.

De Siqueira-Silva, D.H., Saito, T., dos Santos-Silva, A.P., da Silva-Costa, R., Psenicka, M. \& Yasui, G.S. 2018. Biotechnology applied to fish reproduction: tools for conservation. Fish Physiology and Biochemistry, 44: 1469-1485. 
Diemer, O., Neu, D.H., Sary, C., Finkler, J.K., Boscolo, W.R. \& Feiden, A. 2012. Artemia sp. na alimentação de larvas de jundiá (Rhamdia quelen). Ciência Animal Brasileira, 13: 175-179.

Feiden, A., Hayashi, C. \& Boscolo, W.R. 2006. Desenvolvimento de larvas de surubim-do-iguaçu (Steindachneridion melanodermatum) submetidas a diferentes dietas. Revista Brasileira de Zootecnia, 35: 2203-2210.

Froese, R. \& Pauly, D. 2015. FishBase. World Wide Web electronic publication. [https://www.fishbase.de/]. Reviewed: January 12, 2019.

Godinho, H.P. 2007. Estratégias reprodutivas de peixes aplicadas à aquicultura: bases para o desenvolvimento de tecnologias de produção. Revista Brasileira de Reprodução Animal, 31: 351-360.

Inoue, L., Ceccarelli, P. \& Senhorini, J. 2003. A larvicultura e a alevinagem do pintado e do cachara. Revista Panorama da Aqüicultura, 13: 15-21.

Leonardo, A.F.G., Romagosa, E., Borella, M.I. \& Batlouni, S.R. 2004. Induced spawning of hatcheryraised Brazilian catfish, cachara Pseudoplatystoma fasciatum (Linnaeus, 1766). Aquaculture, 240: 451461.

Ludwig, L.A.M., Gomes, E. \& Artoni, R.F. 2005. Um método de reprodução induzida para o surubim Steindachneridion melanodermatum (Siluriformes, Pimelodidae) do Rio Iguaçu. Publicatio UEPG, Ciências Biológicas e da Saúde: 11 pp.

Luz, R.K. \& Zaniboni-Filho, E. 2002. Larvicultura do mandi-amarelo Pimelodus maculatus Lacédède, 1803 (Siluriformes: Pimelodidae) em diferentes densidades de estocagem nos primeiros dias de vida. Revista Brasileira de Zootecnia, 31: 560-565.

Luz, R., Santos, J., Pedreira, M. \& Teixeira, E. 2011. Effect of water flow rate and feed training on "pacamã" (Siluriforme: Pseudopimelodidae) juvenile production. Arquivo Brasileiro de Medicina Veteri-nária e Zootecnia, 63: 973-979.

Murgas, L.D.S., de Oliveira Felizardo, V., Ferreira, M.R., Veras, G.C., de Souza, E. \& Andrade, D.A.d.J.P. 2012. Eficiência reprodutiva em espécies nativas de peixes de água doce. Ciência Animal, 22(1): 197-206.

Nascimento, N.F., Pereira-Santos, M., Piva, L.H., Manzini, B., Fujimoto, T., Senhorini, J.A., Yasui, G.S. \& Nakaghi, LSO. 2017. Growth, fatty acid composition, and reproductive parameters of diploid and triploid yellowtail tetra Astyanax altiparanae. Aquaculture, 471: 163-171.

Received: 14 May 2019; Accepted: 19 February 2020
Nogueira, L.B., Azevedo, P.G., Canelhas, M.R., Bedore, A.G., Lopes, J.M. \& Godinho, H.P. 2012. Induced spawning and early ontogeny in hatchery-reared catfish Zungaro jahu (Siluriformes: Pimelodidae). Neotropical Ichthyology, 10: 89-98.

Piferrer, F., Beaumont, A., Falguiere, J.-C., Flajshans, M., Haffray, P. \& Colombo, L. 2009. Polyploid fish and shellfish: production, biology and applications to aquaculture for performance improvement and genetic containment. Aquaculture, 293: 125-156.

Schutz, J.H., Weingartner, M., Zaniboni-Filho, E. \& Nuñer, A. 2008. Crescimento e sobrevivência de larvas de suruvi Steindachneridion scriptum nos primeiros dias de vida: influência de diferentes alimentos e fotoperíodos. Boletim do Instituto de Pesca, 34: 443-451.

Segura, L., Hayashi, C., De Souza, S. \& Soares, C. 2004. Canibalismo entre larvas de pintado, Pseudoplatystoma corruscans, cultivadas sob diferentes densidades de estocagem. Acta Scientiarum Biological Sciences, 26: 299-302.

Shibatta, O.A., Novelli, J.L., Dias, J.H.P., de CastroBritto, S.G. \& Caetano-Filho, M. 2011. Reproduction of duckbill catfish Sorubim lima in captivity (Siluriformes, Pimelodidae) by means of hormonal induction. Semina: Ciências Agrárias, 32: 363-372.

Solis-Murgas, L., Felizardo, V., Ferreira, M., Andrade, E. \& Veras, G. 2011. Importância da avaliação dos parâmetros reprodutivos em peixes nativos. Revista Brasileira de Reprodução Animal, 35: 186-191.

Toussaint, A., Charpin, N., Brosse, S. \& Villéger, S. 2016. Global functional diversity of freshwater fish is concentrated in the Neotropics while functional vulnerability is widespread. Scientific Reports, 6(22125).

Vieira-Sampaio, E. \& Yoshimi, S. 2006. Biologia reprodutiva e desova induzida de duas espécies de bagres (Osteichthyes: Siluriformes) da bacia do rio São Francisco. Acta Scientiarum. Biological Sciences, 28(3): 263-268.

Woynarovich, E. \& Horváth, L. 1983. A propagação artificial em peixes de águas tropicais: manual de extensão. FAO/CODEVASF/CNPq, Brasília.

Yasui, G., Fujimoto, T., Sakao, S., Yamaha, E. \& Arai, K. 2011. Production of loach (Misgurnus anguillicaudatus) germ-line chimera using transplantation of primordial germ cells isolated from cryopreserved blastomeres. Journal of Animal Science, 89: 23802388.

Yasui, G.S., Senhorini, J.A., Shimoda, E., Pereira-Santos, M., Nakaghi, L.S.O., Fujimoto, T., Arias-Rodriguez, L. \& Silva, L.A. 2015. Improvement of gamete quality and its short-term storage: an approach for biotechnology in laboratory fish. Animal, 9: 464-470. 